\title{
G1010206
}

安定余裕を指定する PID オートチューニング方法

小坂 学 ${ }^{* 1}$, 田邊 雄 $^{* 2}$

\section{PID autotuning method for assigning stability margins}

\author{
Manabu KOSAKA ${ }^{* 1}$ and Yuu TANABE ${ }^{* 2}$ \\ ${ }^{* 1}$ Kinki Univ. Dept. of Mechanical Engineering \\ Kowakae3-4-1, Higashiosaka city, Osaka, Japan
}

The PID control is widely used to control mechanical systems. It is useful to assign desired stability margins. Conventionally, the process has been approximated to model process because of appointing stability margins of the control system. However, there is a problem that a difference occurs between true process and similar process. There is a method to design the control system in limit cycle response to solve it. However this method is able to set only phase margin. In this paper, using the limit cycle to design control system and adding a delay element to that. This method can design stability margin with a desirable value. Experiment result is shown the usefulness of this method.

Key Words : PID, Limit-cycle, Autotuning

\section{1. 粕吾}

機械を制御する多くの場面で用いられている制御方法に PID 制御があり，このPID 制御系の安定余裕を指定で きることは設計の際に有用である. 従来は制御対象の伝達関数を 2 次遅れ系などに近似し，安定余裕を指定した 制御器の設計を行うという方法があるが，この方法では制御対象の伝達関数が高次になるほど，設定した安定余 裕と実際の制御系の安定余裕との間に誤差が生じてしまうという問題点がある ${ }^{(1),(2)}$.こういった問題を解決する ために伝達関数の近似を行わずに制御系を設計するという方法が提案されているが ${ }^{(3)}$, 多くの場合, 伝達関数は 周波数応答にフィットするように同定されるため，実際と誤差が生じてしまう．そこで本研究ではリミットサイ クルで直接, 限界振動を測定し, 位相余裕を望ましい值に指定する制御器を設計し, さらにむだ時間要素を加え て位相を遅らせることでゲイン余裕望ましい値になるまで大きくするという方法を新たに提案する.リミットサ イクルを用いて制御系を設計する方法は過去に提案されているが，位相余裕しか指定できないという問題がある (4). 提案法では制御対象の近似を行わないので誤差が生じず, むだ時間要素を調節することで位相余裕とゲイン余 裕の両方を望ましい值に設計できる．そしてこの提案法の有用性をモータ制御で検証する.

\section{2. 提案方法}

\section{$2 \cdot 1$ リミットサイクルによる制御対象の限界振趵の把握}

リミットサイクルとは, 図 2(a)に示すように制御対象の出力信号が正の値の場合は負で一定の入力信号を加え, 出力信号が負の值の場合は正で一定の出力信号を加えるという操作を行うことで入力と出力位相が-180 度ずれた 状態となる自励振動である. 図 2(b)に示すように入出力の位相差が-180 であるので, このときの応答が制御対 象の限界振動である。つまり限界周波数と限界ゲインを測定できる．またこの方法には，限界感度法と違、制御 対象が発散して壊れてしまう恐れがないという利点もある.

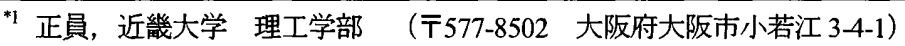

*2 学生員, 近畿大学

E-mail:1333330302@kindai.ac.jp
}

[No.14-1] 日本機械学会 2014 年度年次大会講演論文集〔2014.9.7-10, 東京] 
制御対象 $G(s)$ にリミットサイクルを発生させ，その時の入出力信号を測定する. そしてその信号の周期から制 御対象の限界周波数 $\omega_{u}$ を測定し, 入出力信号の基本波の振幅比から $\left|G\left(j \omega_{u}\right)\right|$ を測定する. これらを用いてルー プ整形を行うことで， $\omega_{u}$ で指定した位相余裕を持つように PID ゲインを設計することができる(5). 図 1 (a)にモ 一タにリミットサイクルを発生させた際の入出力の波形を示寸. 図 1 (a)から, モータへの入力電圧 $u(t)$ の波形と, 出力 $y(t)$ であるモータの回転速度の波形が-180 度ずれていることから, リミットサイクルが発生していることが 確認できる. また, 図 2 は制御対象のボード線図であり，限界周波数 $\omega_{u}$ は図 1 (a) の $y(t)$ の周波数から, $\left|G\left(j \omega_{u}\right)\right|$ は $u(t)$ と $y(t)$ の基本波の振幅比からわかる.

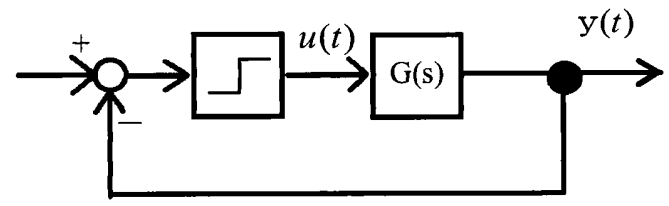

(a) Block diagram

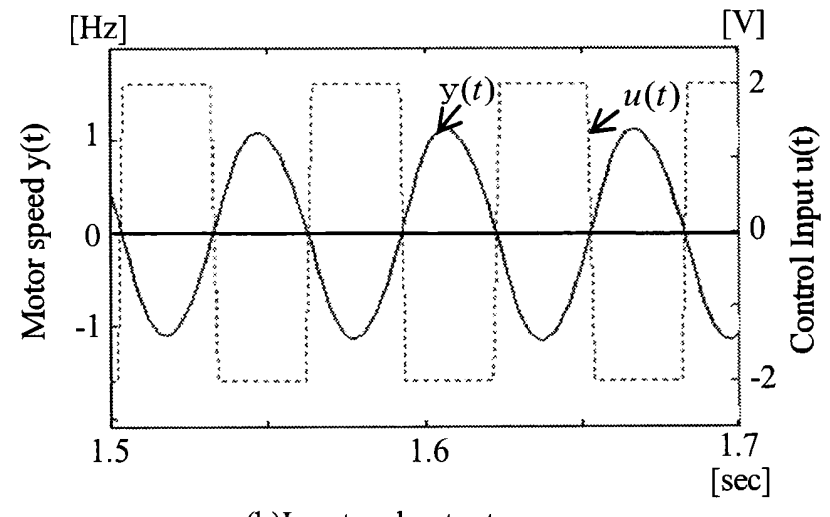

(b)Input and output response

Figure 1 limit-cycle

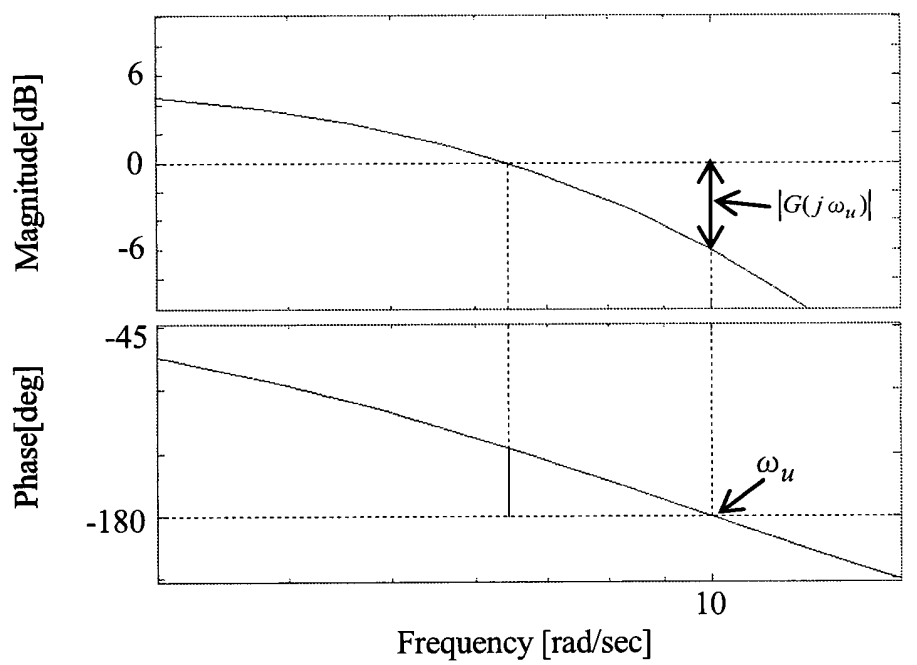

Figure 2 Bode diagram of $\mathrm{G}(\mathrm{s})$

\section{$2 \cdot 2$ リミットサイクルによる PID 制御系のゲイン余裕の把㩧}

図3 (a)に周波数 $\omega_{u}=10(\mathrm{rad} / \mathrm{sec})$ で位相余裕 $60(\mathrm{deg})$ を持つようにループ整形で設計した時の PID制御系のボード 線図を示す.ループ整形を行うことで図のように $\omega_{u}$ で位相余裕 $\mathrm{P}_{\mathrm{M}}$ を持つように設計できる(5). しかし，位相交 差周波数 $\omega_{g m}$ とゲイン余裕 $G_{M}$ はループ整形では指定することができない. そこで, 図 $3(\mathrm{~b})$ に示すように PID 制 御系にリミットサイクルを発生させることで $\omega_{g m}$ と $\left|G\left(j \omega_{g m}\right)\right|$ を測定し, その結果から $G_{M}$ を求める. この $G_{M}$ 
が望ましい值でない場合は，むだ時間要素を加えて位相を遅らせた制御系にリミットサイクルを発生させること で限界周波数 $\omega_{u 2}$ と限界ゲイン $\left|G\left(j \omega_{u 2}\right)\right|$ を測定する. $\omega_{u 2}$ は $\omega_{u}$ よりも小さいので, これらの值を用いてル 一プ整形を行うことで制御帯域を下げることができ，ゲイン余裕を大きくすることができる．図 4 にむだ時間要 素を加えた場合に位相が $\omega_{u}$ から $\omega_{u 2}$ に変化することを示す. この操作を, 制御系が望ましいゲイン余裕を持 つまで繰り返し行う.

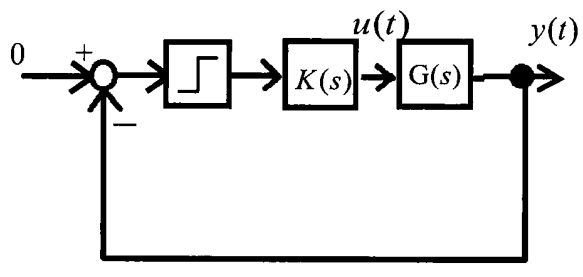

(a) Block Diagram

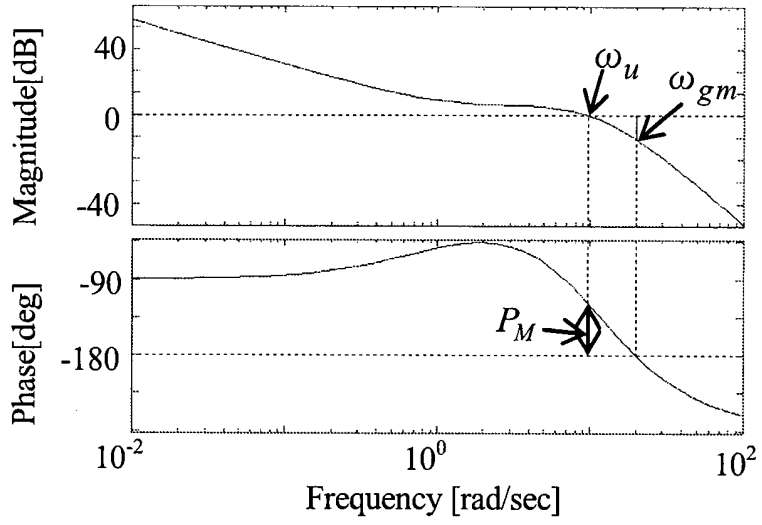

(b) Bode Diagram

Figure 3 PID controller process

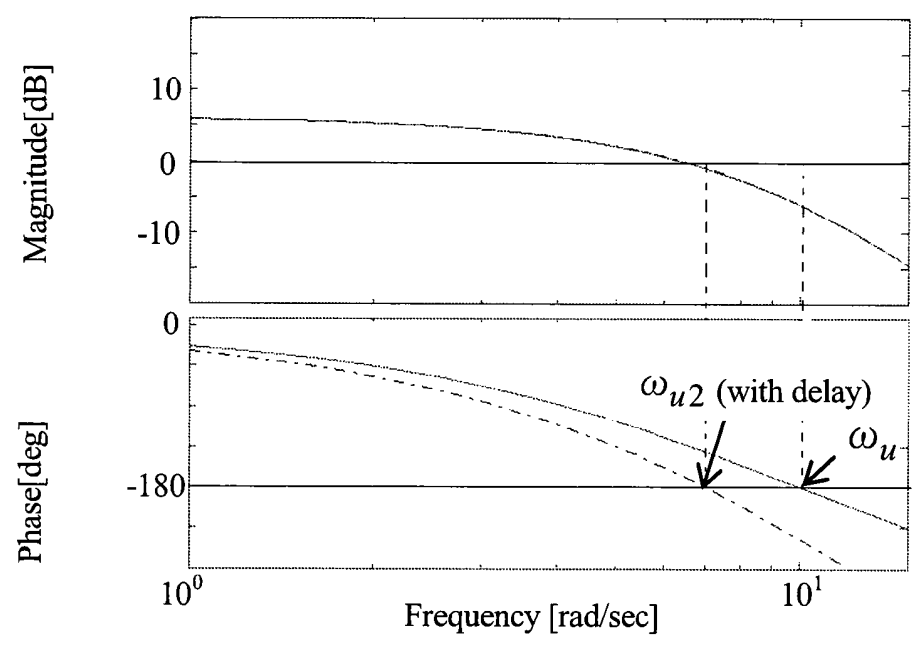

Figure 4 Bode diagram of $\mathrm{G}(\mathrm{s})$ with/without delay

\section{3. 实験方法}

この章では提案法の有効性をブラシ付き DC モータの速度制御実験によって検証する.

\section{3・1 实殹装证}

本研究では MABUCHI-MOTOR 社製の DC モータである RE280RA を制御対象とし， ロータリーエンコーダ OME-360-2MCA-205-015-00 によってモータの回転角を検出する. そのロータリーエンコーダより送られてきた信 号を mbed NXP LPC1768 マイコンで処理することで PID 制御を行う. マイコンからの指令電圧はモータドライバ TA7291P で電圧を調整した後にモータに加えられる. 


\section{$3 \cdot 2$ 实験手順}

この節では実験方法の手順について述べる. サーボ制御の場合は位相余裕は 40〜60[deg]ゲイン余裕は 10〜 20[dB]の值が望ましいとされているので, この值を持つように設計する(5).

\section{$3 \cdot 2 \cdot 1$ 手順 1}

DC モータの回転角をエンコーダから検出し，周波数が正の時には負の電圧を，周波数が負の時は正の電圧を DC モータに加えることでリミットサイクルを発生させ，限界周波数 $\omega_{u}$ を測定する.

\section{$3 \cdot 2 \cdot 2$ 手順 2}

周波数 $\omega_{u}$ でPID 制御系が位相余裕 $60[\mathrm{deg}]$ を持つようにループ整形でPID ゲインを求める.

\section{$3 \cdot 2 \cdot 3$ 手順 3}

ループ整形によって求めたPIDゲインを持つPID制御系のゲイン余裕と位相交差周波数を知るためにリミ ットサイクルを発生させ，その時の振幅と周波数を測定する.

\section{$3 \cdot 2 \cdot 4$ 手順 4}

制御系のゲイン余裕が望ましい值でなかった場合は，制御対象にリミットサイクルを発生させる際にむだ時 間要素を加えて位相を遅らせることで $\omega_{u}$ を調整する.

\section{$3 \cdot 2 \cdot 5$ 手順 5}

手順 1〜4 を制御系が望ましい安定余裕を持つまで繰り返し行う.

\section{4. 英験結果}

DC モータの速度制御について位相余裕が $60[\mathrm{deg}]$, ゲイン余裕が $10[\mathrm{~dB}]$ 20[dB]になるように提案法を用いて $\mathrm{PID}$ 制御系を設計したところ，むだ時間を加えなかった場合は $\omega_{u}=116.4[\mathrm{rad} / \mathrm{s}]$ でゲイン余裕は $1.9[\mathrm{~dB}]$ で望まし い值ではなかった．そこで，むだ時間を加えて $\omega_{u}=64[\mathrm{rad} / \mathrm{s}]$ に調整したところ，ゲイン余裕は $10.5[\mathrm{~dB}]$ となり望 ましい安定余裕を持つ PID 制御系を設計することができた. 図 5 に $\omega_{u}$ の值とその時の制御系のゲイン余裕の関 係を示す．同図より， $\omega_{u}$ を小さくすることでゲイン余裕の值が大きくなっていることがわかる.

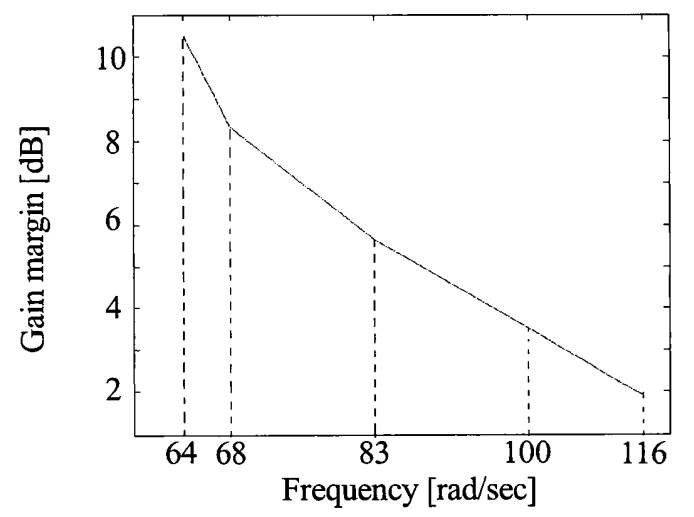

Figure 5 Relationship between $\omega_{u}$ and $G_{M}$ 


\section{5. 結吾}

DC モータの PID 制御系の安定余裕を設定するために提案法を用いて設計を行ったところ, 望ましい安定 余裕をもつ制御系を設計することが出来た. この方法を用いることで, 制御対象の伝達関数を近似する必要 がないので，設定した安定余裕とのずれが発生することを防ぐことが出来る.

\section{文献}

（1）小西 明, 石田 義久, “指定されたグイン余裕と位相余裕をもった PID 調節器の設計について”, 油空圧講演論文 集, Vol.12, No. 2 (2000), pp. 67-69.

(2) Ya-Gang Wang, Wen-Jian Cai, and Zhi-Gang Shi , "PID autotuning for integrating processes with specifications on gain and phase margins", Proseedings of the American Control Conference, Vol. 2001, No. 3, (2001) , pp. 2181-2185.

(3) Qing-Guo Wang, Ho-Wang Fung, Yu Zhang, "PID tuning with exact gain and phase margins", ISA Transactions, Vol.38, (1999), pp. 243-249.

(4) K. J. ÅSTRÖM, T. HÄGGLUND, "Automatic Tuning of Simple Regulators with Specifications on Phase and Amplitude Margins", Automatica, Vol.20, No.5, (1984), pp.645-651

(5) 小坂 学, “高校数学でマスターする制御工学”、コロナ社 (2012) 